\title{
Field-Based Estimates of Thermal Tolerance Limits for Trout: Incorporating Exposure Time and Temperature Fluctuation
}

\author{
Kevin E. Wehrly* AND Lizhu Wang \\ Institute for Fisheries Research, Michigan Department of Natural Resources, \\ and University of Michigan, 212 Museums Annex, Ann Arbor, Michigan 48109-1084, USA \\ Matthew Mitro \\ Wisconsin Department of Natural Resources, Science Operation Center, \\ 2801 Progress Road, Madison, Wisconsin 53716-3339, USA
}

\begin{abstract}
We used temperature and fish data from streams across Michigan and Wisconsin to estimate upper thermal tolerance limits for brook trout Salvelinus fontinalis and brown trout Salmo trutta. Tolerance limits were estimated for the maximum daily mean temperature (MEANT), maximum daily maximum temperature (MAXT), and maximum daily temperature range (RNGT) at exposure lengths of 1, 3, 7, 14, 21, $28,35,42,49,56$, and $63 \mathrm{~d}$. We found no difference in the upper thermal tolerance limit for brook and brown trout. For time periods of $1-14 \mathrm{~d}$, the upper temperatures tolerated by trout decreased rapidly from $25.3^{\circ} \mathrm{C}$ to $22.5^{\circ} \mathrm{C}$ for MEANT and from $27.6^{\circ} \mathrm{C}$ to $24.6^{\circ} \mathrm{C}$ for MAXT. For time periods from 21 to $63 \mathrm{~d}$, the upper temperatures tolerated by trout declined more gradually from $22.1^{\circ} \mathrm{C}$ to $21.0^{\circ} \mathrm{C}$ for MEANT and from $24.2^{\circ} \mathrm{C}$ to $22.9^{\circ} \mathrm{C}$ for MAXT. The $7-\mathrm{d}$ upper tolerance limit was $23.3^{\circ} \mathrm{C}$ for MEANT and $25.4^{\circ} \mathrm{C}$ for MAXT. The maximum RNGT tolerated by trout varied as a function of mean temperature and length of exposure. Our findings suggest that chronic temperature effects as well as temperature fluctuation play an important role in limiting salmonid distributions and therefore should be considered when developing management objectives and water quality standards.
\end{abstract}

Water temperature is an important factor shaping the distribution and abundance patterns of stream fishes, especially salmonids (Binns and Eiserman 1979; Bowlby and Roff 1986; Stoneman and Jones 2000; Wehrly et al. 2003). Temperature affects fishes directly by controlling rates of metabolism, feeding, and growth (Brett 1971; Elliott 1981) and indirectly by affecting prey availability (Hinz and Wiley 1998) and mediating competitive interactions (De Staso and Rahel 1994; Taniguchi et al. 1998; Reese and Harvey 2002). Because temperature is a major determinant of habitat suitability, estimating the thermal tolerance of fishes is of considerable value to resource managers. Thermal tolerance limits can be used to prioritize restoration efforts, to assess risks associated with human-induced changes in water temperature (Eaton and Scheller 1996; Keleher and Rahel 1996), and to develop waterquality criteria to protect fishes from elevated temperatures (U.S. EPA 1976).

Thermal tolerance of fishes traditionally has been estimated by using laboratory methods to determine values such as the critical thermal maximum (CTM) or the upper incipient lethal temperature (UILT). Although these methods have been used extensively to

\footnotetext{
* Corresponding author: wehrlyke@michigan.gov
}

Received July 7, 2006; accepted November 20, 2006 Published online March 8, 2007 develop temperature protection standards, the applicability of laboratory-based thermal tolerance limits to fishes in natural settings has been an issue of growing concern (Dickerson and Vinyard 1999; Selong et al. 2001; Johnstone and Rahel 2003; Schrank et al. 2003; Meeuwig et al. 2004). This concern stems, in part, from the use of unnatural thermal regimes such as rapidly increasing (CTM) or constant temperatures (UILT) in the determination of upper lethal limits. Because streams typically exhibit diel temperature fluctuations, laboratory-based tolerance values may not reflect the thermal stress experienced by fishes in nature.

An alternative approach for estimating thermal tolerance is to use field observations to identify temperatures that correspond to the limits of a species' distribution (Eaton et al. 1995; Welsh et al. 2001; Huff et al. 2005). For example, Eaton et al. (1995) used a national dataset of temperature and fish presence to estimate the thermal tolerance of 30 species by determining the 95th percentile of the maximum weekly mean temperature where each species was found. Field-based approaches are attractive because they rely on the thermal regimes experienced by fishes in nature. In addition, because these approaches are based on a species' realized thermal niche (Magnuson et al. 1979), they account for variation in other factors (e.g., prey availability, behavioral thermoregulation, 


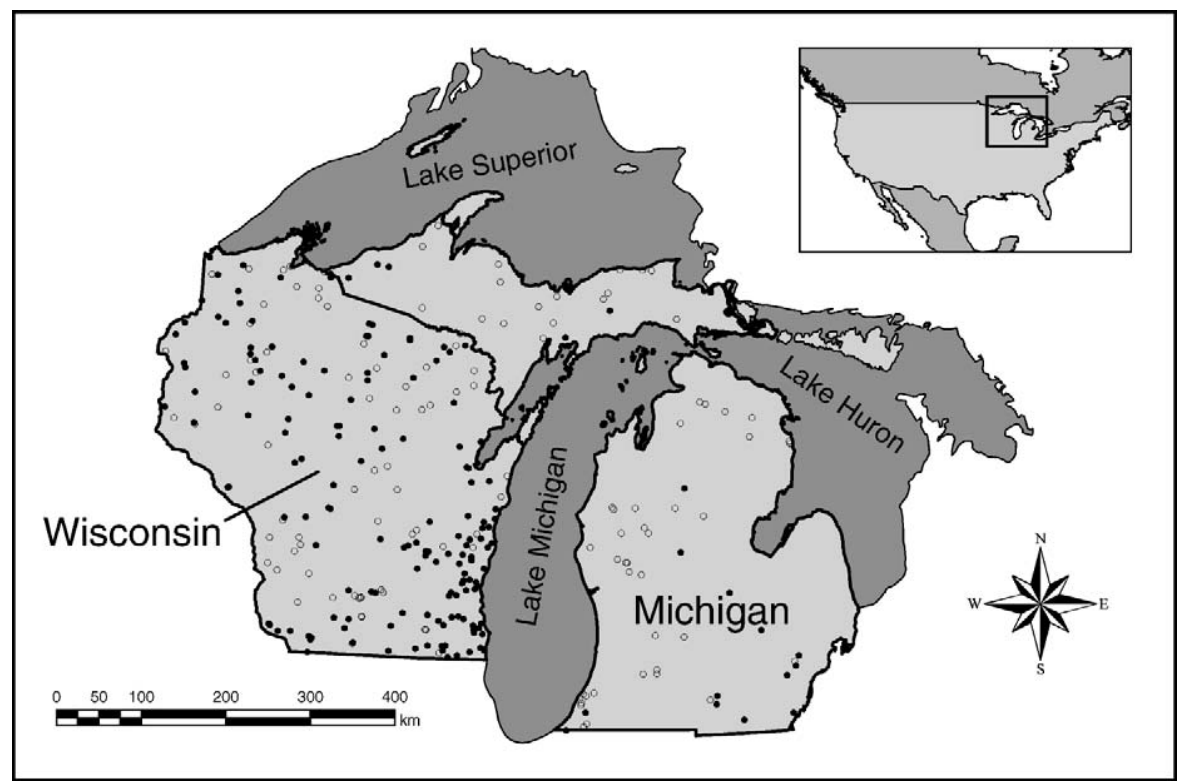

FIGURE 1.-Locations of study sites across Michigan and Wisconsin at which brook and brown trout were present (open circles) or absent (solid circles).

competitive interactions) that ultimately determine the thermal niche that a species occupies.

Most estimates of thermal tolerance derived from laboratory and field approaches are based on relatively short time periods $(\leq 7 \mathrm{~d})$. A common assumption of these studies is that temperature standards developed from short-term exposure (e.g., 7-d UILT) are adequate to protect fish populations from the lethal effects of temperature during longer exposure times. However, the chronic effects of temperature are poorly understood, and some evidence suggests fish exposed to temperatures that are sublethal during acute tests may experience delayed mortality during longer exposure times (Selong et al. 2001). Because long-term exposure to elevated temperatures may be an important factor determining habitat suitability and species performance, estimating thermal tolerance limits for both acute and chronic exposure would be desirable.

The goal of this study was to use a field-based approach to estimate the upper thermal tolerance limit of fishes for both short- and long-term exposure under natural conditions. We used temperature and fish data from streams across Michigan and Wisconsin to estimate thermal tolerance limits for brook Salvelinus fontinalis and brown trout Salmo trutta. Tolerance limits were estimated for the mean, maximum, and range at different exposure lengths. We then compared our results with published laboratory and field observations.

\section{Methods}

This study was based on data from 285 wadable stream sites located across Michigan and Wisconsin (Figure 1). Streams in this region primarily drain lowelevation landscapes of glacial origin. Patterns of climate, topography, and land use are relatively similar across the two states, and spatial variation in groundwater loading plays an important role in shaping the temperature and flow regimes in these streams (Wehrly et al. 2006). The study sites represented a diverse set of stream types that support coldwater, coolwater, and warmwater fish assemblages and were spread across five major ecoregions. One hundred sites occurred in the Northern Lakes and Forest ecoregion that extends across northern Wisconsin and Michigan. The remaining sites in Wisconsin were distributed across the North Central Hardwood Forests (33 sites), the Driftless Area (34 sites), and the Southeastern Wisconsin Tillplains (76 sites). The remaining sites in Michigan occurred in the Southern Michigan/Northern Indiana Drift Plains (32 sites), and in the rest of the four ecoregions (10 sites). Sites were chosen based on the availability of fish assemblage and water temperature data collected by the Michigan Department of Natural Resources and the Wisconsin Department of Natural Resources from 1991 to 2000. Fish and temperature data were not always collected at the same location. Temperature data were matched to a fish sampling site if 
temperature sampling occurred within $1 \mathrm{~km}$ of the fish sampling location and if no tributaries entered the stream between the fish and temperature sampling locations.

Fish assemblage data were collected during lowflow conditions from June to September. The length of each sampling site was about 35 times the mean stream width, or a minimum of $100 \mathrm{~m}$. The entire length of each site was electrofished by a single-pass with either a backpack or tow-barge electrofishing unit. An effort was made to collect all fish observed, and all captured fish were identified and counted. Brook and brown trout abundance for each site was standardized to number of fish/100 $\mathrm{m}$ of stream length.

Summer (June through August) stream temperatures were measured at each site at 30- to 60-min intervals with digital recording thermographs. Temperature and fish data were collected during the same year at 171 sites. For the remaining sites, temperature data were matched to fish data if temperature and fish sampling occurred within 5 years. Because interannual variation (average among-year standard error [SE] in mean temperature for the exposure periods considered = $0.66, N=36$; Wehrly et al. unpublished data) in thermal regime tends to be relatively low for the streams in this region, we assumed that temperature data collected in any given year were representative of the typical thermal conditions at those sites. We also assumed that seasonal emigration to escape warmer water temperatures was minimal and that fish experienced the thermal conditions measured at those sites (Schrank et al. 2003).

Temperature measurements for each site were summarized into daily mean, daily maximum, and daily range. From these summaries we determined the maximum daily mean, maximum daily maximum, and maximum daily range for the sampling season for each site. To account for length of exposure to the daily temperature regimes at each site, we first determined the average daily mean, average daily maximum, and average daily range for the periods of $3,7,14,21,28$, $35,42,49,56$, and $63 \mathrm{~d}$. We then determined the maxima of each temperature measure for each time period. For example, to determine the maximum 3-d daily mean for a site, we first calculated the 3-d moving average of the daily means at that site for every 3-d interval for the period of record. We then selected the highest of the 3-d moving average values for the subsequent analysis. This process was repeated for the remaining time intervals and for the daily mean, daily maximum, and daily range, which resulted in a total of 33 temperature summaries for each site. Hereafter, the maximum $n$-d daily mean temperature will be referred to as $n$-d MEANT, the maximum $n$-d daily maximum temperature will be referred to as $n$-d MAXT, and the maximum $n$-d daily range will be referred to as $n$-d RNGT, where $n=$ exposure period.

To estimate the upper thermal tolerance limits for MEANT and MAXT, we determined the warmest 5\% of the locations where trout were present, based on the approach of Eaton et al. (1995). Because our goal was to estimate thermal tolerance for various lengths of exposure period, we determined the 95th percentile temperature for the periods of $1,3,7,14,21,28,35$, $42,49,56$, and $63 \mathrm{~d}$. To determine the warmest $5 \%$ of the locations for MEANT and MAXT and for each exposure period, we first plotted the temperatures $(y$ axis) where trout were found against exposure period ( $x$-axis). Next, to reduce the influence of extreme values on this analysis, we discarded two of the warmest sites from each of the plots (Eaton et al. 1995). We then fitted a 95\% quantile regression (BLOSSOM software; Cade and Richards 2001) to each plot. Separate regressions were fitted for brook trout and brown trout. Because temperature characteristics were similar between stocked and nonstocked sites, we included data from stocked sites in this analysis. Differences in regression quantile models for brook and brown trout were assessed with a rank-score test (Cade and Richards 2001). The resulting 95th percentile temperatures for each exposure period were then plotted with length of exposure period on the $y$-axis and temperature on the $x$-axis. These plots were fitted with an exponential function, which allowed for direct comparison with curves of LT50 (temperatures that were lethal to half the fish in the sample) published in the literature.

Estimating the temperature fluctuation limits tolerated by trout required a different approach because the highest RNGT at sites where trout were present was dependent on both the length of exposure period and the MEANT at those sites. To estimate the maximum temperature fluctuation, we first plotted RNGT ( $y$-axis) against MEANT ( $x$-axis) for sites where trout were found for each exposure period. We then fitted a $95 \%$ quantile regression to each plot, using the linearized form of the modified Ricker function: $\log _{e}(\mathrm{RNGT})=$ $\log _{e}\left(B_{0}\right)+B_{1} \cdot \log _{e}($ MEANT $)+B_{2} \cdot$ MEANT. We chose this dome-shaped function because the magnitude of temperature fluctuation tolerated by fish is expected to decline as mean temperature approaches their upper thermal tolerance, a result of reduced growth and increased mortality (Hokanson et al. 1977; Dickerson and Vinyard 1999; Johnstone and Rahel 2003; Meeuwig et al. 2004). Inspection of our data suggested a decrease in the magnitude of temperature fluctuation tolerated at higher mean temperatures, especially during extended exposure periods. 


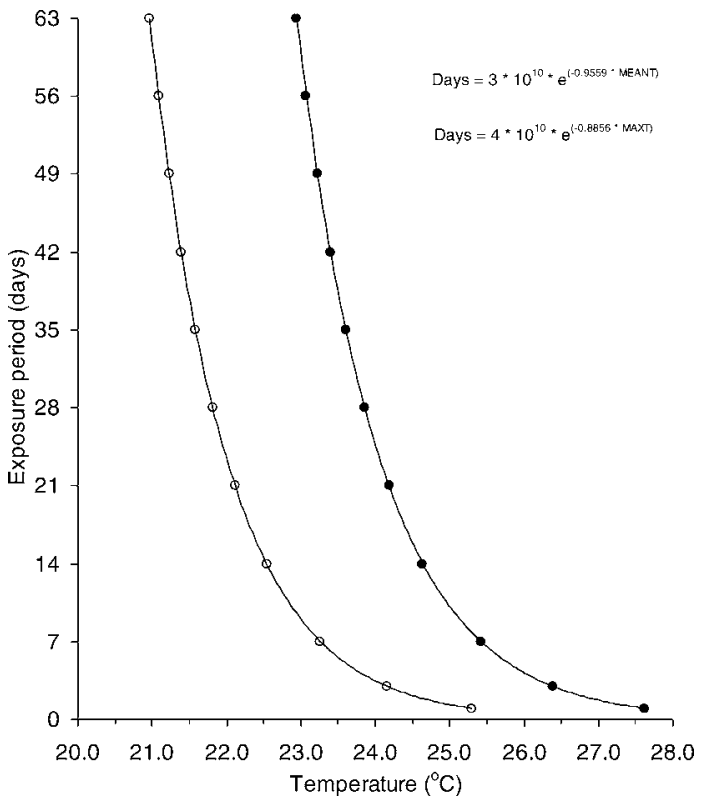

Figure 2.-Estimates of two measures of thermal tolerance- the maximum daily mean temperature (MEANT; open circles) and the maximum daily maximum temperature (MAXT; solid circles) — of brook and brown trout as functions of exposure period. Thermal tolerance was determined from the $95 \%$ MEANT and MAXT values at sites where trout were present.

\section{Results}

The study sites represented a broad range of water temperature conditions. Mean temperatures at sites where trout were present varied from $11.3^{\circ} \mathrm{C}$ to $26.1^{\circ} \mathrm{C}$ for $1-\mathrm{d}$ MEANT and from $9.6^{\circ} \mathrm{C}$ to $22.3^{\circ} \mathrm{C}$ for $63-\mathrm{d}$ MEANT. Mean temperatures at sites where trout were absent varied from $18.7^{\circ} \mathrm{C}$ to $30.3^{\circ} \mathrm{C}$ for $1-\mathrm{d}$ MEANT and from $14.3^{\circ} \mathrm{C}$ to $26.0^{\circ} \mathrm{C}$ for $63-\mathrm{d}$ MEANT. Maximum temperatures at sites where trout were present varied from $12.9^{\circ} \mathrm{C}$ to $28.1^{\circ} \mathrm{C}$ for 1 -d MAXT and from $10.7^{\circ} \mathrm{C}$ to $24.0^{\circ} \mathrm{C}$ for $63-\mathrm{d}$ MAXT. Maximum temperatures at sites where trout were absent varied from $20.0^{\circ} \mathrm{C}$ to $34.3^{\circ} \mathrm{C}$ for $1-\mathrm{d}$ MAXT and from $16.8^{\circ} \mathrm{C}$ to $28.4^{\circ} \mathrm{C}$ for $63-\mathrm{d} \mathrm{MAXT}$. Temperature range at sites where trout were present varied from $2.1^{\circ} \mathrm{C}$ to $15.8^{\circ} \mathrm{C}$ for 1 -d RNGT and from $1.1^{\circ} \mathrm{C}$ to $6.6^{\circ} \mathrm{C}$ for $63-\mathrm{d}$ RNGT. Temperature range at sites where trout were absent varied from $2.5^{\circ} \mathrm{C}$ to $17.5^{\circ} \mathrm{C}$ for $1-\mathrm{d}$ RNGT and from $1.1^{\circ} \mathrm{C}$ to $8.7^{\circ} \mathrm{C}$ for 63 -d RNGT.

Brook trout or brown trout were present at 116 sites (Figure 1), of which half of these sites were stocked. Thirty-nine sites contained only brook trout, 47 sites contained only brown trout. The remaining sites contained a mixture of trout species, 22 of these sites having brook and brown trout. Trout abundance (all species combined) at the study sites varied from 0.1 to $268.5 \mathrm{fish} / 100 \mathrm{~m}$ and averaged $27.5 \mathrm{fish} / 100 \mathrm{~m}$.

Slopes and intercepts of quantile regressions describing the relationship between temperature and length of exposure time for brook and brown trout were not significantly different for MEANT (slope $P=$ 0.40 ; intercept $P=0.70$ ) and MAXT (slope $P=0.14$; intercept $P=0.22$ ). Therefore, data for the two species were pooled and common quantile regression models were used to estimate thermal tolerance for each exposure period.

Plots of exposure time versus estimates of the upper thermal tolerance for MEANT and MAXT showed a negative exponential decline (Figure 2). Thermal tolerance estimates for MAXT were approximately $2^{\circ} \mathrm{C}$ warmer than those for MEANT for all exposure periods. For time periods of $1-14 \mathrm{~d}$, the upper temperatures tolerated by trout decreased rapidly from $25.3^{\circ} \mathrm{C}$ to $22.5^{\circ} \mathrm{C}$ for MEANT and from $27.6^{\circ} \mathrm{C}$ to $24.6^{\circ} \mathrm{C}$ for MAXT. For time periods from 21 to $63 \mathrm{~d}$, the upper temperatures tolerated by trout declined more gradually from $22.1^{\circ} \mathrm{C}$ to $21.0^{\circ} \mathrm{C}$ for MEANT and from $24.2^{\circ} \mathrm{C}$ to 22.9 for MAXT. The 7-d upper tolerance limit was $23.3^{\circ} \mathrm{C}$ for MEANT and 25.4 for MAXT.

The maximum temperature fluctuation tolerated by trout varied as a function of mean temperature and length of exposure (Figure 3). For all time periods, the relationship between 95th percentile RNGT and MEANT was curvilinear, the maximum RNGT tolerated by trout occurring at intermediate MEANTs. The maximum tolerated RNGT shifted downward and occurred at cooler MEANTs as length of exposure period increased. The maximum tolerated RNGT was $10.6^{\circ} \mathrm{C}$ for $1-\mathrm{d}, 8.8^{\circ} \mathrm{C}$ for $3-\mathrm{d}, 7.8^{\circ} \mathrm{C}$ for $7-\mathrm{d}, 7.0^{\circ} \mathrm{C}$ for $21-\mathrm{d}$, and $6.4^{\circ} \mathrm{C}$ for $63-\mathrm{d}$ exposure.

\section{Discussion}

The estimated thermal tolerance limits for short-term exposure in this study are comparable to the laboratory observations for brook, brown, and rainbow trout Oncorhynchus mykiss (Table 1; Figure 4). Most of the UILT values based on exposure periods of $7 \mathrm{~d}$ or less fell between our estimates for the 7-d MEANT $\left(23.3^{\circ} \mathrm{C}\right)$ and $7-\mathrm{d}$ MAXT $\left(25.4^{\circ} \mathrm{C}\right)$ tolerance limit. We are aware of no studies that have determined the upper thermal tolerance of these species for longer time periods. Selong et al. (2001) determined UILT values for bull trout Salvelinus confluentus for time periods up to $60 \mathrm{~d}$. The temperature-survival curve reported by Selong et al. (2001) was similar in shape to our fieldbased curves for thermal tolerance. Bull trout have the lowest upper thermal tolerance limits among salmo- 

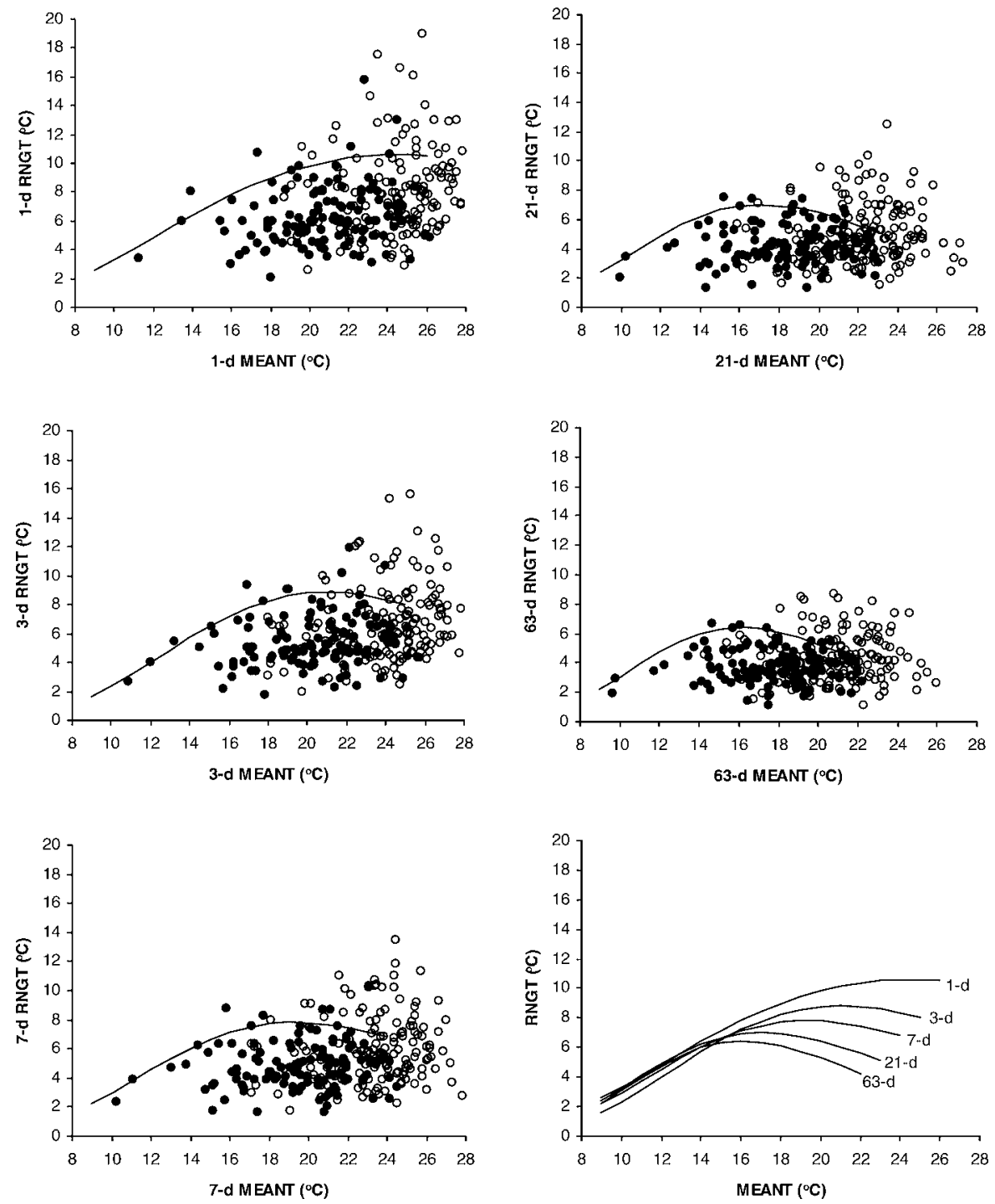

FIGURE 3.- Relationships between the maximum daily mean temperature (MEANT) and the maximum daily temperature range (RNGT) for exposure periods of $1,3,7,21$, and $63 \mathrm{~d}$ at sites with (solid circles) and without (open circles) brook and brown trout. The lines represent estimates of the maximum RNGT tolerated by trout as a function of MEANT, as determined from the $95 \%$ quantile regression of RNGT at sites where trout were found. The bottom right panel shows all of the tolerance curves presented in the other panels.

nids, which probably explains why the bull trout curve fell so close to our MEANT tolerance curve.

Comparison of our results with other field-based observations was also limited to short exposure times. The 1-d MAXT tolerance value for Michigan and Wisconsin streams $\left(27.6^{\circ} \mathrm{C}\right)$ was slightly higher than the 1-d maximum summer values (range $=24.0^{\circ} \mathrm{C}$ to $26.5^{\circ} \mathrm{C}$ ) reported in the literature (see references in Table 1). We found that trout were present in a relatively large number of sites having temperatures of at least $26^{\circ} \mathrm{C}$ and that these sites support moderate standing stocks (Figure 5). The 7-d MEANT $\left(23.3^{\circ} \mathrm{C}\right)$ determined in this study fell midway between the maximum weekly mean temperature tolerance for brook $\left(22.3^{\circ} \mathrm{C}\right)$ and brown trout $\left(24.1^{\circ} \mathrm{C}\right)$ reported by Eaton et al. (1995). This result is not surprising, given that we combined data from brook and brown trout streams to estimate thermal tolerance.

Our estimated trout upper MEANT tolerance limits progressively decreased for periods greater than $7 \mathrm{~d}$. 
TABLE 1.-Critical thermal maxima (CTM), upper incipient lethal temperature (UILT), and field observations of upper temperature tolerances for brook, brown, and rainbow trout.

\begin{tabular}{|c|c|c|c|c|c|}
\hline Species & $\mathrm{CTM}\left({ }^{\circ} \mathrm{C}\right)$ & UILT $\left({ }^{\circ} \mathrm{C}\right)$ & $\begin{array}{c}\text { Acclimation } \\
\text { temperature }\left({ }^{\circ} \mathrm{C}\right)\end{array}$ & Field observation $\left({ }^{\circ} \mathrm{C}\right)$ & Reference \\
\hline \multirow[t]{11}{*}{ Brook trout } & $28.7-29.8$ & & $10-20$ & & Lee and Rinne (1980) \\
\hline & $28.3-30.8$ & & $8-20$ & & Selong et al. (2001) \\
\hline & 29 & & 10 & & De Staso and Rahel (1994) \\
\hline & & $25.3(3 \mathrm{~d})$ & 24 & & Fry et al. (1946) \\
\hline & & $24.5(7 \mathrm{~d})$ & & & McCormick et al. (1972) \\
\hline & & & & 24 (Maximum summer temperature) & Picard et al. (2003) \\
\hline & & & & 25.6 (Maximum summer temperature) & Barton et al. (1985) \\
\hline & & & & 26.5 (Maximum summer temperature) & Bowlby and Roff (1986) \\
\hline & & & & 24.2-26.3 (Maximum summer temperature) & Binns and Eiserman (1979) \\
\hline & & & & 24 (Maximum weekly temperature) & Meisner (1990) \\
\hline & & & & 22.3 (Maximum weekly mean temperature) & Eaton et al. (1995) \\
\hline \multirow[t]{7}{*}{ Brown trout } & $29.0-29.9$ & & $10-20$ & & Lee and Rinne (1980) \\
\hline & 29.9 & & 20 & & Elliott and Elliott (1995) \\
\hline & & 24.7 (7 d) & 22 & & Elliott (1981) \\
\hline & & $25.3(7 \mathrm{~d})$ & 23 & & Frost and Brown (1967) \\
\hline & & & & 25 (Maximum summer temperature) & Bowlby and Roff (1986) \\
\hline & & & & 24.2-26.3 (Maximum summer temperature) & Binns and Eiserman (1979) \\
\hline & & & & 24.1 (Maximum weekly mean temperature) & Eaton et al. (1995) \\
\hline \multirow[t]{9}{*}{ Rainbow trout } & $28-29.8$ & & $10-20$ & & Currie et al. (1998) \\
\hline & $28.5-29.4$ & & $10-20$ & & Lee and Rinne (1980) \\
\hline & 29.4 & & & & Rodnick et al. (2004) \\
\hline & & $26.6(1 \mathrm{~d})$ & 24 & & Charlon et al. (1970) \\
\hline & & $25.6(7 \mathrm{~d})$ & 16 & & Hokanson et al. (1977) \\
\hline & & $26.2(7 \mathrm{~d})$ & 24.5 & & Kaya (1978) \\
\hline & & & & 25 (Maximum summer temperature) & Bowlby and Roff (1986) \\
\hline & & & & 25.6 (Maximum summer temperature) & Barton et al. (1985) \\
\hline & & & & 24.2-26.3 (Maximum summer temperature) & Binns and Eiserman (1979) \\
\hline
\end{tabular}

This result, in addition to the finding of Selong et al. (2001), suggests that chronic temperature effects may play a role in limiting salmonid distributions. It is well established that exposure to temperatures near the upper tolerance limit results in reduced feeding, conversion efficiency, and growth of salmonids (Brett 1971; Elliott 1981; Dickerson and Vinyard 1999; Selong et al. 2001; Johnstone and Rahel 2003; Meeuwig et al. 2004). Such sublethal stresses disrupt the normal functions of fish, which may impact the probability of survival, especially during extended periods of exposure. Because delayed mortality associated with sublethal effects is not obvious during short-term laboratory studies, the thermal water quality criteria based on 7-d UILT may not be an adequate safeguard to ensure that $50 \%$ of the population can survive indefinitely (Selong et al. 2001).

Other factors associated with extended exposure to elevated temperatures may also affect salmonid distributions. Behavioral thermoregulation is well known in fishes, and individuals may seasonally emigrate to more favorable stream reaches when temperatures become unsuitable during the warmest part of the year (Meisner 1990; Hayes et al. 1998; but see Schrank et al. 2003). Trout distributions may also be influenced by temperature through effects on competitive interactions. Trout are competitively inferior to coolwater species at temperatures near their upper thermal tolerance limit (Reeves et al. 1987; Taniguchi et al. 1998; Reese and Harvey 2002). The exact mechanism whereby chronic exposure to elevated temperatures limits salmonid distributions is unknown. Additional work is needed to determine how long-term exposure may limit salmonid distributions and to determine the relative importance of long-term versus short-term exposure on the persistence of trout populations.

Our results indicate that trout in Michigan and Wisconsin streams tolerated short-term exposure ( $\leq 7 \mathrm{~d})$ to maximum temperatures that were higher than the recommended water temperature criteria derived from laboratory 7-d UILT (U.S. EPA 1976). Similar observations have been made for salmonids in other regions under laboratory (Lee and Rinne 1980; Dickerson and Vinyard 1999; Johnstone and Rahel 2003; Meeuwig et al. 2004) and field settings (Table 1; Lohr et al. 1996; Dunham et al. 2003; Schrank et al. 2003; Rodnick et al. 2004). Compared with warmwater fishes, coldwater fishes such as salmonids tend to have lower temperature tolerance but higher resistance to temperatures above the upper incipient lethal temperature (Elliott 1981). Apparently, stream salmonids have adapted to living in cycling thermal environments near their upper tolerance level, where they are exposed to brief periods of near lethal temperatures. These short- 


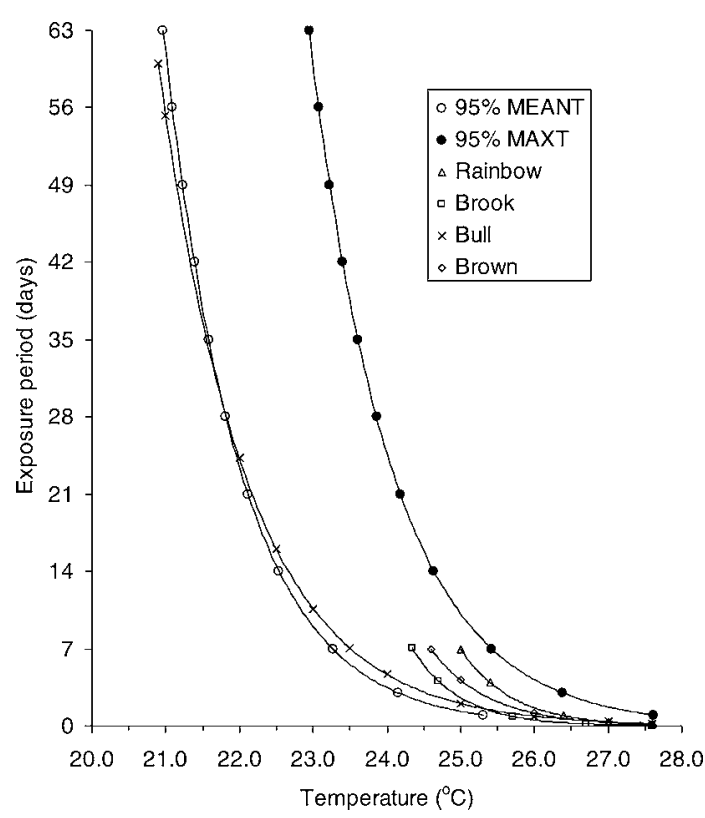

FIGURE 4.-Estimates of thermal tolerance limits from this study and the upper incipient lethal temperatures (UILTs) from published laboratory studies for various trout species as a function of exposure period. Thermal tolerance in this study was determined from the $95 \%$ maximum daily mean temperature (MEANT) and maximum daily maximum temperature (MAXT) at sites where trout were found. The UILT for brook (McCauley 1958), brown (Alabaster and Downing 1966), and rainbow trout (Coutant 1970) were determined for periods up to $7 \mathrm{~d}$; values for bull trout (Selong et al. 2001) were determined for periods up to $60 \mathrm{~d}$.

term exposures are often stressful to fish but their role in limiting persistence remains unclear.

We found that the magnitude of temperature fluctuation tolerated by trout varied as a function of mean temperature and period of exposure. The increase in RNGT at relatively cold mean temperatures represents the upper limit of fluctuations that are possible in these stream systems. Because the coldest sites in this region tend to be small and receive a relatively large proportion of their streamflow from groundwater (Wehrly et al. 2006), these systems are buffered against diel changes in heat inputs and are relatively more stable. As streams become larger, the relative contribution of groundwater decreases, the effectiveness of shading from riparian vegetation decreases, and the magnitude of diel temperature variation tends to increase. In contrast, the decline in RNGT at relatively higher mean temperatures probably represents a physiological response by trout. Several studies have shown that the magnitude of daily temperature variations can affect salmonid stress levels,
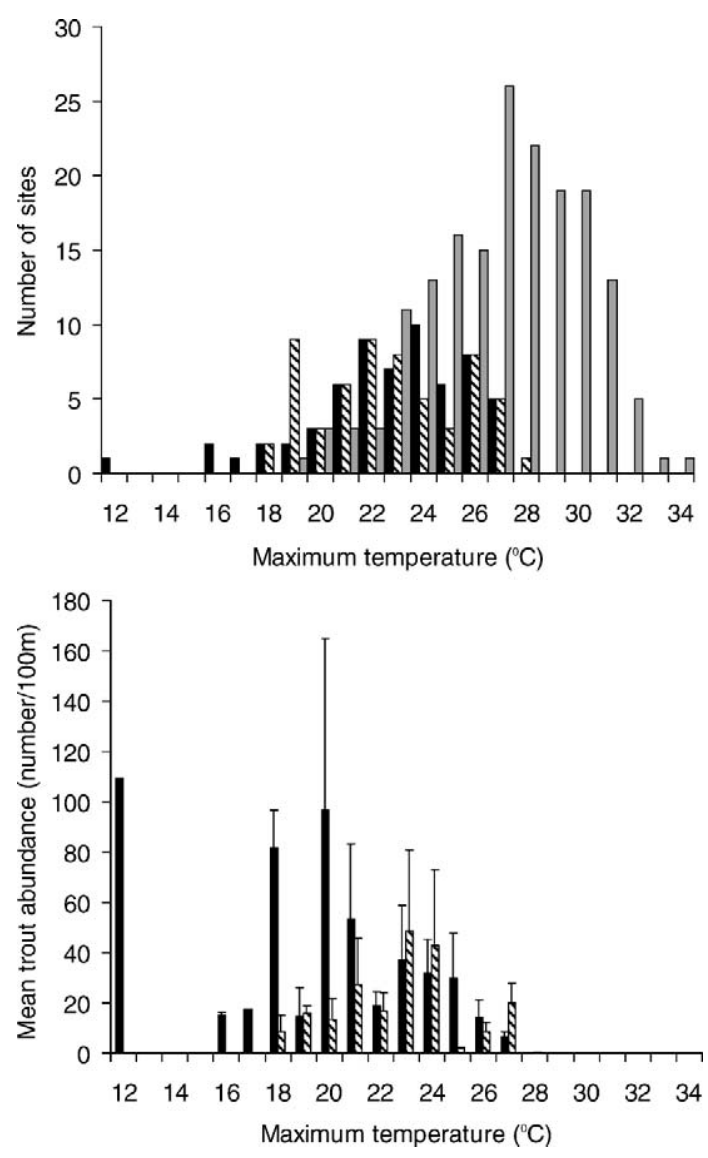

FIGURE 5.- The upper panel shows the distribution of stocked (crosshatched bars) and nonstocked trout streams (dark bars) and streams where trout were absent (gray bars). The lower panel shows the distribution of mean trout abundance at stocked and nonstocked trout streams versus maximum daily temperature.

feeding, growth, survival, and distribution patterns (Thomas et al. 1986; Johnstone and Rahel 2003; Lobon-Cervia 2003; Wehrly et al. 2003; Meeuwig et al. 2004; de la Hoz Franco and Budy 2005). As Meeuwig et al. (2004) noted, the mechanisms underlying the response of fish to temperature fluctuations are unclear and probably result from the stress associated with life in cycling thermal regimes, from costs associated with increased exposure to temperatures near the upper lethal limit, or from an interaction between the two. Nonetheless, our findings, along with the results from a growing number of studies, underscore the importance of temperature variability to the ecology of salmonids and to fish in general.

We found no difference in the temperatures occupied by brook and brown trout and consequently no difference in their upper thermal tolerance limit. Our 
results contrast with the findings of Eaton et al. (1995), who found the 7-d maximum mean temperature tolerance of brook trout $\left(22.3^{\circ} \mathrm{C}\right)$ was slightly lower than that of brown $\left(24.1^{\circ} \mathrm{C}\right)$ and rainbow trout $\left(24.0^{\circ} \mathrm{C}\right)$. Interestingly, the CTM values for brook, brown, and rainbow trout are very similar, indicating that these species have a similar ability to tolerate thermal stress. Upper incipient lethal temperatures from laboratory studies also suggest that short-term tolerance in these species is within $1^{\circ} \mathrm{C}$. Other field observations (Table 1) also support the idea that these species have similar tolerance limits under natural temperature conditions.

The curves developed in this study represent the upper thermal limits at which brook and brown trout can persist for various periods of time. These curves can be used by fishery managers and researchers to classify stream reaches according to their suitability for brook and brown trout. Such an effort can help guide restoration efforts by identifying those reaches that are suitable for stocking, or riparian or instream habitat improvements. Because the curves can be used to estimate the length of time that these species can withstand a particular temperature and the upper temperature that can be tolerated for any period of time, they provide much needed information for the development of water-quality standards. Finally, the curves can be used to identify those populations that are most at risk to anthropogenic changes in temperature related to destruction of riparian buffers (Barton et al. 1985; Li et al. 1994), conversion to impervious surfaces (Wang et al. 2003), and global warming (Eaton and Scheller 1996; Keleher and Rahel 1996).

\section{Acknowledgments}

This work was supported by the Michigan Department of Natural Resources and the Federal Aid in Sport Fish Restoration Fund, Project F-35-R. We thank Allain Rasolofoson for work on the temperature database, Arthur Cooper for GIS support and help with Figures, and Paul Seelbach, Jim Breck for helpful suggestions and insightful discussions about temperature tolerance. Three anonymous reviewers provided helpful comments on this manuscript.

\section{References}

Alabaster, J. S., and A. L. Downing. 1966. A field and laboratory investigation on the effect of heated effluents on fish. Fishery Investigations, Series 1, 6:1-42, London.

Barton, D. R., W. D. Taylor, and R. M. Biette. 1985. Dimensions of riparian buffer strips required to maintain trout habitat in southern Ontario streams. North American Journal of Fisheries Management 5:364-378.

Binns, N. A., and F. M. Eiserman. 1979. Quantification of fluvial trout habitat in Wyoming. Transactions of the American Fisheries Society 108:215-228.

Bowlby, J. N., and J. C. Roff. 1986. Trout biomass and habitat relationships in southern Ontario streams. Transactions of the American Fisheries Society 115:503-514.

Brett, J. R. 1971. Energetic responses of salmon to temperature: a study of some thermal relations in the physiology and freshwater ecology of sockeye salmon (Oncorhynchus nerka). American Zoologist 11:33-113.

Cade, B. S., and J. D. Richards. 2001. User manual for BLOSSOM statistical software. U.S. Geological Survey, Fort Collins, Colorado.

Charlon, N., B. Barbier, and L. Bonnet. 1970. Thermal resistance of rainbow trout (Salmo gairdneri Richardson) to abrupt temperature variations. Annales d'Hydrobiologie 1:73-89.

Coutant, C. C. 1970. Thermal resistance of adult coho (Oncorhynchus kisutch) and jack Chinook (O. tshawytscha) salmon and the adult steelhead trout (Salmo gairdnerii) from the Columbia River. Battelle-Northwest, SEC BNWL-1508 Richland, Washington.

Currie, R. J., A. W. Bennett, and T. L. Beitinger. 1998. Critical thermal minima and maxima of three freshwater game fish species acclimated to constant temperature. Environmental Biology of Fishes 54:187-200.

de la Hoz Franco, E. A., and P. Budy. 2005. Effects of biotic and abiotic factors on the distribution of trout and salmon along a longitudinal stream gradient. Environmental Biology of Fishes 72:379-391.

De Staso, J., III, and F. J. Rahel. 1994. Influence of water temperature on interactions between juvenile Colorado River cutthroat trout and brook trout in a laboratory stream. Transactions of the American Fisheries Society 123:289-297.

Dickerson, B. R., and G. L. Vinyard. 1999. Effects of high chronic temperatures and diel temperature cycles on the survival and growth of Lahontan cutthroat trout. Transactions of the American Fisheries Society 128:516-521.

Dunham, J., R. Schroeter, and B. Rieman. 2003. Influence of maximum water temperature on occurrence of Lahontan cutthroat trout within streams. North American Journal of Fisheries Management 23:1042-1049.

Eaton, J. G., and R. M. Scheller. 1996. Effects of climate warming on fish thermal habitat in streams of the United States. Limnology and Oceanography 41:1109-1115.

Eaton, J. G., J. H. McCormick, B. E. Goodno, D. G. O'Brien, H. G. Stefany, M. Hondzo, and R. M. Scheller. 1995. A field information-based system for estimating fish temperature tolerances. Fisheries 20(4):10-18.

Elliott, J. M. 1981. Some aspects of thermal stress on freshwater teleosts. Pages 209-245 in A. D. Pickering, editor. Stress and fish. Academic Press, New York.

Elliott, J. M., and J. A. Elliott. 1995. The effect of the rate of temperature increase on the critical thermal maximum for parr of Atlantic salmon and brown trout. Journal of Fish Biology 47:917-919.

Frost, W. E., and M. E. Brown. 1967. The trout. Collins, London.

Fry, F. E. J., J. S. Hart, and K. F. Walker. 1946. Lethal temperature relations for a sample of young speckled trout (Salvelinus fontinalis). University of Toronto 
Studies, Biological Series 54. (Publication of the Ontario Fisheries Research Laboratory 66:9-35.)

Hayes, D. B., W. W. Taylor, M. T. Drake, S. M. Marod, and G. E. Whelan. 1998. The value of headwaters to brook trout (Salvelinus fontinalis) in the Ford River, Michigan, USA. Pages 175-185 in M. J. Haigh, J. Krecek, G. S. Rajwar, and M. P. Kilmartin, editors. Headwaters: water resources and soil conservation. A. A. Balkema, Rotterdam, The Netherlands.

Hinz, L. C., Jr., and M. J. Wiley. 1998. Growth and production of juvenile trout in Michigan streams: influence of potential ration and temperature. Michigan Department of Natural Resources, Fisheries Research Report 2042, Ann Arbor.

Hokanson, K. E., C. F. Kleiner, and T. W. Thorslund. 1977. Effects of constant temperatures and diel temperatures on specific growth and mortality rates and yield of juvenile rainbow trout, Salmo gairdneri. Journal of the Fisheries Research Board of Canada 34:639-648.

Huff, D. D., S. L. Hubler, and A. N. Borisenko. 2005. Using field data to estimate the realized thermal niche of aquatic vertebrates. North American Journal of Fisheries Management 25:346-360.

Johnstone, H. C., and F. J. Rahel. 2003. Assessing temperature tolerance of Bonneville cutthroat trout based on constant and cycling thermal regimes. Transactions of the American Fisheries Society 132:92-99.

Kaya, C. M. 1978. Thermal resistance of rainbow trout from a permanently heated stream and two hatchery strains. Progressive Fish-Culturist 40:138-142.

Keleher, C. J., and F. J. Rahel. 1996. Thermal limits to salmonid distributions in the Rocky Mountain region and potential habitat loss due to global warming: a geographical information systems (GIS) approach. Transactions of the American Fisheries Society 125:1-13.

Lee, R. M., and J. N. Rinne. 1980. Critical thermal maxima of five trout species in the southwestern United States. Transactions of the American Fisheries Society 109: 632-635.

Li, H. W., G. A. Lamberti, T. N. Pearsons, C. K. Tait, J. L. Li, and J. C. Buckhouse. 1994. Cumulative effects of riparian disturbances along high desert trout streams of the John Day basin, Oregon. Transactions of the American Fisheries Society 123:627-640.

Lobon-Cervia, J. 2003. Spatiotemporal dynamics of brown trout production in a Cantabrian stream: effects of density and habitat quality. Transactions of the American Fisheries Society 132:621-637.

Lohr, S. C., P. A. Byorth, C. M. Kaya, and W. P. Dwyer. 1996. High-temperature tolerances of fluvial Arctic grayling and comparisons with summer river temperatures of the Big Hole River, Montana. Transactions of the American Fisheries Society 125:933-939.

Magnuson, J. J., L. B. Crowder, and P. A. Medvick. 1979. Temperature as an ecological resource. American Zoologist 19:331-343.

McCauley, R. W. 1958. Thermal relations of geographic races of Salvelinus. Canadian Journal of Zoology 36:655-662.

McCormick, J. H., K. E. Hokanson, and B. R. Jones. 1972. Effects of temperature on growth and survival of young brook trout, Salvelinus fontinalis. Journal of the Fisheries Research Board of Canada 29:1107-1112.
Meeuwig, M. H., J. B. Dunham, J. P. Hayes, and G. L. Vinyard. 2004. Effects of constant and cyclical thermal regimes on growth and feeding of juvenile cutthroat trout of variable sizes. Ecology of Freshwater Fish 13:208-216.

Meisner, J. D. 1990. Potential loss of thermal habitat for brook trout, due to climatic warming, in two southern Ontario streams. Transactions of the American Fisheries Society 119:282-291.

Picard, C. R., M. A. Bozek, and W. T. Momot. 2003. Effectiveness of using summer thermal indices to classify and protect brook trout streams in northern Ontario. North American Journal of Fisheries Management 23: 206-215.

Reese, C. D., and B. C. Harvey. 2002. Temperature-dependent interactions between juvenile steelhead and Sacramento pikeminnow in laboratory streams. Transactions of the American Fisheries Society 131:599-606.

Reeves, G. H., F. H. Everest, and J. D. Hall. 1987. Interactions between the redside shiner (Richardsonius balteatus) and the steelhead trout (Salmo gairdneri) in western Oregon: the influence of water temperature. Canadian Journal of Fisheries and Aquatic Sciences 44:1603-1613.

Rodnick, K. J., A. K. Gamperl, K. R. Lizars, M. T. Bennett, R. N. Rausch, and E. R. Keeley. 2004. Thermal tolerance and metabolic physiology among redband trout populations in southeastern Oregon. Journal of Fish Biology 64:310-335.

Schrank, A. J., F. J. Rahel, and H. C. Johnstone. 2003. Evaluating laboratory-derived thermal criteria in the field: an example involving Bonneville cutthroat trout. Transactions of the American Fisheries Society 132: 100-109.

Selong, J. H., T. E. McMahon, A. V. Zale, and F. T. Barrows. 2001. Effect of temperature on the growth and survival of bull trout, with application of an improved method of determining thermal tolerance in fishes. Transactions of the American Fisheries Society 130:1026-1037.

Stoneman, C. L., and M. L. Jones. 2000. The influence of habitat features on the biomass and distribution of three species of southern Ontario stream salmonines. Transactions of the American Fisheries Society 129:639-657.

Taniguchi, Y., F. J. Rahel, D. C. Novinger, and K. G. Gerow. 1998. Temperature mediation of competitive interactions among three fish species that replace each other along longitudinal stream gradients. Canadian Journal of Fisheries and Aquatic Sciences 55:1894-1901.

Thomas, R. E., J. A. Gharrett, M. G. Carls, S. D. Rice, A. Moles, and S. Korn. 1986. Effects of fluctuating temperature on mortality, stress, and energy reserves of juvenile coho salmon. Transactions of the American Fisheries Society 115:52-59.

U.S. EPA (Environmental Protection Agency). 1976. Quality criteria for water. U.S. EPA, Washington, D.C.

Wang, L., J. Lyons, and P. Kanehl. 2003. Impacts of urban land cover on trout streams in Wisconsin and Minnesota. Transactions of the American Fisheries Society 132: 825-839.

Wehrly, K. E., M. J. Wiley, and P. W. Seelbach. 2003. Classifying regional variation in thermal regime based on stream fish community patterns. Transactions of the American Fisheries Society 132:18-38.

Wehrly, K. E., M. J. Wiley, and P. W. Seelbach. 2006. 
Influence of landscape features on summer water temperatures in lower Michigan streams. Pages 113127 in R. M. Hughes, L. Wang, and P. W. Seelbach, editors. Landscape influences on stream habitats and biological assemblages. American Fisheries Society, Symposium 48, Bethesda, Maryland.
Welsh, H. H., Jr., G. R. Hodgson, B. C. Harvey, and M. F. Roche. 2001. Distribution of juvenile coho salmon in relation to water temperatures in tributaries of the Mattole River, California. North American Journal of Fisheries Management 21:464-470. 